\title{
RESEARCH ON THE EVALUATION INDEX SYSTEM OF THE RISK MANAGEMENT LEVEL OF ASSET MANAGEMENT OF CHINA'S COMMERCIAL BANKS
}

\author{
Yinjie Fang ${ }^{*}$, Shiran Liu² \\ ${ }^{1}$ School of Economics and Management, North China Electric Power University, 2th Beinong Road, Changping District, Beijing, China \\ ${ }^{2}$ School of Electrical Engineering and Telecommunications, University of New South Wales, 330 Anzac Parade, Kensington, Sydney, Australia
}

\author{
*Corresponding Author's E-mail: Inuckjsyyq@126.com
}

This is an open access article distributed under the Creative Commons Attribution License, which permits unrestricted use, distribution, and reproduction in any medium, provided the original work is properly cited.

\section{ARTICLE DETAILS}

\section{Article History:}

Received 12 March 2018

Accepted 12 April 2018

Available online 15 May 2018

\section{ABSTRACT}

Asset Management of China's Commercial Banks will face more and more challenges from other financial institutions during the new era of asset management, which will inevitably lead to the reform of the asset management of commercial banks in China. How to better measure the risk management level of the assets management business in China? How to evaluate the outcome and efficiency of risk management of the asset management business in our country objectively and comprehensively? Solving those problems is urgent now. This article builds an evaluation index system for asset management of China's commercial banks and make a comprehensive analysis of it in order to provide some references for better transition of asset management of China's commercial banks.

\section{KEYWORDS}

Risk Management, Wealth Investment Product, Commercial Bank.

\section{INTRODUCTION}

Based on a study, the asset management business of China's commercial banks was initially emerged as a product of financial reform with an innovative form in response to China's interest rate control [1]. Commercial banks issued different forms of financial products through asset management business to cope with the interest rate limits and help its clients gain more profit [2]. By this way, the banks can also raise more funds. However, with the progress of interest rates marketization and the liberalization of financial licenses, non-bank financial institutions have entered the asset management business. The commercial bank's asset management business with traditional risk management mode can no longer meet the development requirement of times. Study showed commercial banks urgently need to improve its risk management and evaluation system of asset management [3]. The new risk management concept, the new risk management model should be applied to its asset management business, which will make China's commercial bank asset management business back to its essence [4].

\section{PROBLEMS EXISTING IN RISK MANAGEMENT OF ASSET} MANAGEMENT BUSINESS OF CHINA COMMERCIAL BANKS

We believe that commercial banks' asset management mainly involves three aspects, namely, absorption of capital, use of funds and corporation management level. The risk management level of these three aspects can directly reflect risk management level of entire asset management business. Therefore, we will analyze existing problems in risk management of China's commercial banks' asset management business from these three aspects

\subsection{The Absorption of Capital}

According to research, in a country with high savings rate, the absorption of capital is not the primary issue for risk management [5]. In our country, the risk at this aspect mainly comes from the unreasonable design of wealth management products and being poor in implementation of the principle of "risk-matching" at present.

Nowadays, most of the wealth investment products sold by China's commercial banks are still designed with certain expected return rate [6]. Most products have similar content which cannot meet the diverse needs of its clients. Therefore, the category of wealth investment products must be rational and diversified at first. For example, the product form may be transformed to, like net worth product, project financing product and structural product. Second, the product can also be designed according to different client group, such as retail clients, high net worth clients and institutional clients. In addition, China's commercial banks are poor in due diligence in selling phase. Our banks do not clearly acquire their client's financial position and risk tolerance level, not to mention selling the certain product to certain client. From the clients' point of view, in order to pursue high returns, they also tend to ignore the possible use of funds and other risk points. However, due to the existing yield guarantee of some wealth investment products issued by commercial banks, "rigid payment" is a very possible result and the risk of asset management business will increase. Therefore, in order to control the risk in the capital side, commercial banks should design rational wealth investment products and strictly obey the principle that certain products must be sold to certain client according to their financial position and risk tolerance level.

\subsection{The Use of Funds}

As for the use of funds, we believe that the problems can be concluded in three aspects. The first is the collocation of investment products. Nowadays, most of China's commercial banks' funds are invested in overcapacity industries. Therefore, the percentage of problem loans rate is at high position. According to a study, banks should broaden the scope of investment and optimize the allocation of investment portfolio. In addition, some commercial banks' asset management business still follows the traditional credit mode and provide credit support in the form of "short-term capital, long-term investment", resulting in the unjustified use of leverage. The second is investment management, commercial banks are widely criticized for the widespread usage of "asset pool" mode [7]. In this 
mode, commercial banks sell wealth investment products continuously, and put the capital into a certain capital pool, which will lead to "maturity mismatching", being hard to implement risk-remote measure, the opaque of investment operations, increasing the difficulty of supervision and so on. Commercial banks are also poor in post-investment management, the resulting risks are not supposed to be ignored. The third problem is the overlapping between investment operation and self-operated business. Some commercial banks use capitals of wealth management to meet the regulatory indicators at specific time points. What is more, some of commercial banks use those capitals which belong to off-balance-sheet activity to adjust their own balance sheet. In this condition, bank's own risk is increased due to off-balance-sheet risk.

\subsection{Operation management}

For the operation management, we believe its risk management ability can be evaluated from four aspects: (1) the construction of risk management system; (2) information disclosure; (3) planning, decision-making, execution and coordination; (4) information system [8].

The construction of risk management system is the top-level design of risk management and involves all aspects of assets management. Based on the current situation of commercial banks in China, the system should be strengthened to identify, monitor and control all kind of risk in asset management business. Also, information disclosure and post-investment management should be improved. Our commercial banks should establish a full-progress, full-coverage and systematic risk control system to ensure the steady development of asset management business.

For information disclosure, most of our commercial banks still adopt the method of collective operation. Under the "black box" operation of "capital pool" mode, investors and regulators are difficult to identify the investment orientation of capitals. Therefore, improving the disclosure of information and the transparency of operation can also restrict the behavior of commercial banks from outside and improve the risk management level.

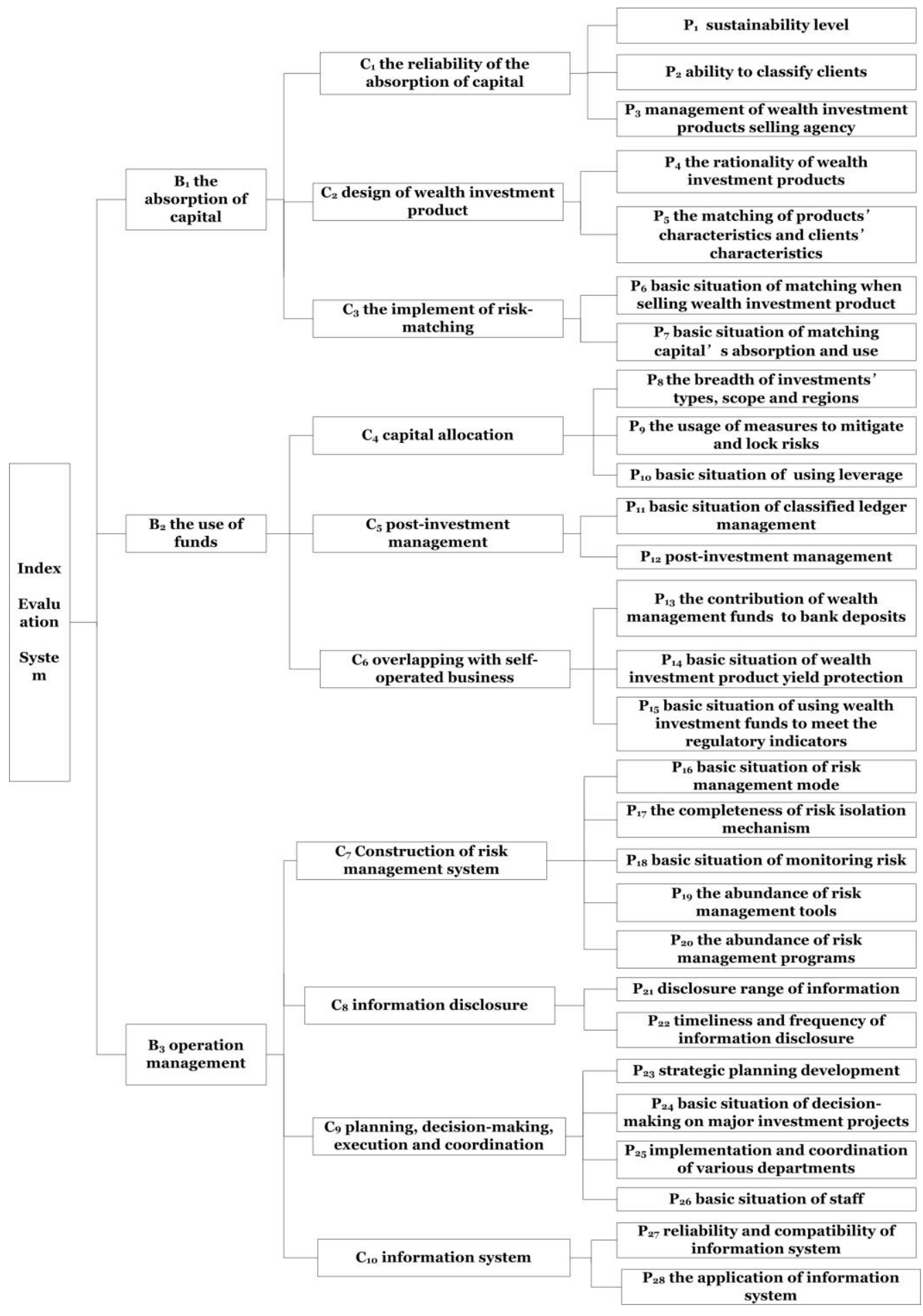

Figure 1: Evaluation Index System 
Due to asset management business involves many departments of the commercial bank, in order to reduce the risk caused by internal management, commercial banks should strengthen the construction of internal control system and execution ability of employees [9]. Moreover, communication and coordination between departments are also significant. In addition, our commercial banks should optimize its staffing structure and absorb more highly-diversified disciplines and highly educated personnel to build a professional and high-quality team, which can also effectively improve the risk management level.
The informatization level of risk management is also an unignorable point at information age. From the risk assessment, the design of all kinds of risk management tools, the background monitoring to terminal experience of clients, every step can examine the reliability of the bank information system. Therefore, developing an excellent information system can effectively reduce the risk of misoperation.

\section{CONSTRUCTION AND ANALYSIS OF EVALUATION INDEX SYSTEM}

Table 1: Final Result of AHP Analysis

\begin{tabular}{|c|c|c|c|c|c|c|c|}
\hline goal & criteria & priorities & subcriteria & priorities & alternative & priorities & order \\
\hline \multirow{28}{*}{$\begin{array}{l}\text { Index } \\
\text { Evaluation } \\
\text { System }\end{array}$} & \multirow{7}{*}{ B1 } & \multirow{7}{*}{0.2500} & \multirow{3}{*}{$\mathrm{C} 1$} & \multirow{3}{*}{0.1108} & P1 & 0.0781 & 4 \\
\hline & & & & & P2 & 0.0234 & 17 \\
\hline & & & & & P3 & 0.0093 & 23 \\
\hline & & & \multirow{2}{*}{ C2 } & \multirow{2}{*}{0.0968} & P4 & 0.0645 & 5 \\
\hline & & & & & P5 & 0.0323 & 10 \\
\hline & & & \multirow[b]{2}{*}{ C3 } & \multirow[b]{2}{*}{0.0424} & P6 & 0.0085 & 25 \\
\hline & & & & & P7 & 0.0339 & 8 \\
\hline & \multirow{8}{*}{ B2 } & \multirow{8}{*}{0.2500} & \multirow{3}{*}{ C4 } & \multirow{3}{*}{0.0714} & $\mathrm{P} 8$ & 0.0327 & 9 \\
\hline & & & & & P9 & 0.0297 & 12 \\
\hline & & & & & P10 & 0.0090 & 24 \\
\hline & & & \multirow{2}{*}{ C5 } & \multirow{2}{*}{0.1429} & P11 & 0.1190 & 2 \\
\hline & & & & & P12 & 0.0239 & 16 \\
\hline & & & \multirow{3}{*}{$\mathrm{C} 6$} & \multirow{3}{*}{0.0357} & P13 & 0.0261 & 15 \\
\hline & & & & & P14 & 0.0067 & 27 \\
\hline & & & & & P15 & 0.0029 & 28 \\
\hline & \multirow{13}{*}{ B3 } & \multirow{13}{*}{0.5000} & \multirow{5}{*}{ C7 } & \multirow{5}{*}{0.3259} & P16 & 0.1756 & 1 \\
\hline & & & & & P17 & 0.0444 & 7 \\
\hline & & & & & P18 & 0.0798 & 3 \\
\hline & & & & & P19 & 0.0150 & 18 \\
\hline & & & & & P20 & 0.0111 & 20 \\
\hline & & & \multirow{2}{*}{ C8 } & \multirow{2}{*}{0.0211} & P21 & 0.0106 & 21 \\
\hline & & & & & P22 & 0.0104 & 22 \\
\hline & & & \multirow{4}{*}{ C9 } & \multirow{4}{*}{0.1018} & P23 & 0.0514 & 6 \\
\hline & & & & & P24 & 0.0305 & 11 \\
\hline & & & & & P25 & 0.0125 & 19 \\
\hline & & & & & P26 & 0.0074 & 26 \\
\hline & & & \multirow{2}{*}{ C10 } & \multirow{2}{*}{0.0512} & P27 & 0.0266 & 13 \\
\hline & & & & & P28 & 0.0266 & 13 \\
\hline
\end{tabular}

Note. $\mathrm{CI}_{\text {total }}=0.0143, \mathrm{RI}_{\text {total }}=0.2594, \mathrm{CR}_{\text {total }}=0.0552$

According to the operation characteristics of commercial banks' asset management business, the status quo of risk management, and the problems we mentioned above, we construct the risk management level evaluation index system, as shown in figure 1.

Next, we construct a set of pairwise comparison matrices according to experts' grading. Each element in an upper level is used to compare the elements in the level immediately below with respect to it. There are 14 pairwise comparison matrices in all, one for the criteria with respect to the goal, three for the subcriteria, ten for the alternative. After that, we calculate $\mathrm{CI}, \mathrm{CR}$ of each matrix to examine the consistency. At last, if the data pass the examination, we use the priorities obtained from the comparisons to weigh the priorities in the level immediately below. Do this for every element. Then for each element in the level below add its weighed values and obtain its overall or global priority. Continue this process of weighing and adding until the final priorities of the alternatives in the bottom most level is obtained. The result is as shown in table 1.

\section{DISCUSSION}

\subsection{For Criteria}

Among three criterions studied in this paper, the weight of operation management (B3) is 0.5 , which is obviously higher than the other two criterion. This conclusion is understandable. When commercial banks manage risk, the most important thing is to design a good risk management system at the top, only in the case that the risk management system is perfect, the operating procedures, responsibilities and rights of various positions constrained by strict rules and arrangements, the behavior of employees can be well controlled, the operating procedures can be well regulated, the operation risk can be reduced. As for absorption of capital and use of funds, the one is front-end of asset management business, the other one is back-end, both two sides interact with each other, the absorption condition of capital will affect the investment, to a certain extent, the profitability will also affect the capital raising. In theory, the weight of the influence of those two factors on the risk management should also be similar. The results of the analysis show that the weights at the fund-level (B1) and product-level (B2) are the same, which is consistent with our viewpoints.

\subsection{For Subcriteria}

From the analysis result, the design and sales of wealth investment products occupy the largest weight which is understandable. Nowadays, commercial banks' wealth investment products are highly concerned on $R \& D$ and operation ability which is invisible for clients. Asset management is a small category of retail finance, the core of retail finance, on the one hand, is clear market segment, on the other hand is the law of large numbers. So, commercial banks need viscosity of its clients. At same time, retail finance also requires commercial banks have the ability to classify their clients fast and respond to its clients' requirement quickly. That is to say, besides designing reasonable wealth investment products, commercial banks should also pay more attention to the classification of their clients, which is not only for the diversified demand of their clients, but also for the requirement of commercial banks to control their operation risk. Meanwhile, the sales of wealth investment products should be well concerned when evaluate the risk management level of asset management business. For example, the well communication between commercial banks and its sales agency, the matching degree of client's characteristics and the products.

After obtaining capital from the issuance of wealth investment products, commercial banks should rationally use these capitals to buy different financial products. According to the theory of financial investment, it is very important to allocate the portfolios well. In the progress, commercial banks should pay attention to the breadth of investment and take reasonable measures to control risk exposure and use leverage rationally to balance risk and return. Beside what are mentioned above, our commercial banks are poor in classified ledger management, which can be identified from the weight of 0.1190 . However, from the perspective of the development trend of asset management, in order to rationally manage risk and make the business operate well, it is also the general trend to carry out separate ledger management on different investment portfolios. Finally, the overlapping between asset management business and self- 
operated business is a historical issue. With the transition of asset management in the new era of asset management, it is believed that this problem will be completely solved in the near future.

As for operation management, we can see from the priorities that the ones with the most weight are risk management mode, the risk monitoring condition, the completeness of the risk isolation mechanism and the formulation of the strategic plan. The weights in the goal are respectively $0.1756,0.0798,0.0514$ and 0.0444 . This shows that commercial banks should set up a comprehensive risk management system that covers all aspects of asset management. The system should be built according to the unique risk characteristics and regulatory requirements of asset management. Commercial banks should build a consummate risk management system from the top, select risk management mode according to their own risk characteristic, make rational strategy plans and strengthen communication and coordination between each department.

\section{REFERENCES}

[1] Ba, S.S. 2013. Research on the Internal Dynamic Mechanism and Risk Management of Wealth Investment Product Development of Commercial Banks, Review of Industrial Economics, 05: 15-19

[2] China Banking Regulatory Commission. 2011. Administration
Methods for the Sale of Wealth Investment Products of Commercial Banks.

[3] Liu, G.F., Sun, J.F. 2017. Research on Transition of Commercial Banks' Asset Management Based on the View of Supply-side Reform, Journal of Regional Financial Research, 01: 54-56

[4] Liu, J.H. 2016. The Innovation Road of Bank's Wealth Management 2.0, Tsinghua Financial Review, 09: 39-42

[5] Luo, L.N. 2016. The Development of Bank in New Era of Asset Management, China Finance, 01: 53-54

[6] Sun, R. 2016. International Experience on Asset Management, China Finance, 01: 57-58

[7] Sun, R., Qiu, M.Y. 2016. Risk Management of Commercial Banks' Asset Management, Tsinghua Financial Review, 09: 53-56

[8] Wang, Y. 2012. The status quo, risk and development direction of commercial banks' capital pool of wealth investment production, Journal of Regional Financial Research, 09: 62-64

[9] Yao, L. 2016. The 3.0 era of Asset Management for Commercial Banks, China Finance, 01: 55-56 